\title{
Paraoxonase1 (PON1) 55 and 192 Polymorphism in Egypt and its impact on the antioxidant status of patients with Bilharzial and Viral liver diseases
}

\author{
Gharib,A, $F^{\mathbf{1}}$, Karam, $R, A^{\mathbf{1}}$, El-Naggar, I, $Z^{\mathbf{1}}$, and Fargaly, $M, E^{2}$. \\ Medical Biochemistry and Tropical Medicine Departments, Faculty of \\ Medicine, Zagazig University
}

\begin{abstract}
Background/Aims: It is now known beyond doubt that viral hepatitis (caused by B or $C$ virus) along with bilharzial infestation (mostly S. mansoni) are the most important factors responsible for the vast majority of morbidity and mortality in Egypt. Based upon the concept that oxidative stress plays a key role in the development and pathogenesis of chronic liver diseases, many of the factors known to have antioxidant properties are to be investigated for purpose of evaluating their role in the defense mechanisms against all oxidant brunts associated with liver diseases. Serum MDA was assayed as a famous marker of oxidative stress, while PON1 enzyme activities were investigated as a marker of antioxidant properties. The polymorphism at 55 and 192 position known to be associated with PON1 enzyme are also investigated in Egyptian normal and chronic liver patients, in order to elucidate whether such polymorphism has any effect on the enzyme activity, and consequently the state of hepatic affection. Whether routine assay of PON1 activity in chronic liver disease patients can be introduced as a non-invasive clue marker for diagnosis and rating the stage of hepatic affection is another aim of the present work. Methods: We studied 75 patients with chronic liver disease (25 patient with chronic Bilharziasis, 25 patients with chronic hepatitis $C, 25$ patients with mixed hepatitis $C$ and bilharzial cirrhosis) and 25 apparently healthy controls. Serum paraoxonase activity and levels of the lipid peroxidation marker (serum malondialdhyde) were measured spectrophotomtrically. PON1 genotyping at positions 55 and 192 were analyzed by $P C R$, restriction fragment length polymorphism and agarose gel electrophoresis. Results: the present work showed that chronic liver disease (viral and/or bilharzial) are associated with elevated oxidative stress (as indicated by increased MDA level) together with reduced PON1-activities, which is regarded as an antioxidant tool. The frequency of investigated polymorphism at 55 and 192 position were found to be of no statistical significance between patients and control groups. The MDA and PON1 values did correlate with standard liver function. Conclusion: The present work could introduce the assay of PON1 activity in the serum as a non-invasive, specific and reliable marker in a trial to assess the state of liver affection in chronic hepatic diseases.
\end{abstract}




\section{INTRODUCTION}

In Egypt, viral hepatitis along with Schistosoma mansoni infestation is the major cause of chronic liver disease ${ }^{1}$.HCV infection is characterized by increased markers of oxidative stress ${ }^{2}$. Lipid peroxidation products are increased in serum, peripheral blood mononuclear cells (PBMC), and liver specimen from hepatitis patients ${ }^{3}$. Schistosoma mansoni causes liver disease by inducing granulomatous inflammation. This favors formation of reactive oxygen species, including superoxide ions, hydrogen peroxide and hydroxyl radicals all of which may induce lipid peroxidation ${ }^{4}$, so the antioxidant status may play an important role in the development of chronic liver disease.

Paraoxonase is an ester hydrolase that is synthesized almost exclusively in the liver and which circulates in the plasma associated with HDL ${ }^{5}$. PON1 is the best studied member of a family of mammalian enzymes that includes PON2and PON3, which share 60\% sequence identity with PON1. PON1 and PON3 reside in the cholesterolcarrying particles HDL (good cholesterol), whereas PON2 is found in many tissues including the liver, Lungs, brain and heart ${ }^{6} . \mathrm{PON}_{1}$ is a 355 amino acid glycoprotein with a molecular weight of approximately 43 $\mathrm{kDa}$, and a serum concentration of about $50 \mathrm{mg} / \mathrm{L}^{7}$. PON1 degrades oxidized phospholipids in low-density lipoproteins (LDL) and HDL and, as such, plays a role in the organism's antioxidant system ${ }^{8-11}$.
Alterations in circulating PON1 levels are associated with a variety of diseases involving oxidative stress ${ }^{12-14}$ which, as mentioned is associated with chronic hepatic derrangement ${ }^{15-17}$

Serum paraoxonase gene is located at position q $21-\mathrm{q} 22$ on the long arm of chromosome 7 , closely linked to the gene of cystic fibrosis. Human paraoxonase gene (PON1) shows two polymorphisms at its coding region (amino acid at positions 192 and 55) and 5 polymorphisms at the promoter regions of PON1 gene (positions 909, 824, 162, 126 and 107) ${ }^{\mathbf{1 8}}$. The coding region of $\mathrm{PON}_{1}$ gene contains two polymorphic sites: a leucine (L) methionine (M) transition at position $55(55 \mathrm{~L} / \mathrm{M})$, and glutamine (Q) to arginine (R) transition at position192(192Q/R) ${ }^{\mathbf{1 9}}$. The polymorphisms affect the hydrolytic activity of the PON1 isoenzymes with respect to certain substrates, such as paraoxon and lipid peroxides $^{20}$. The dominant effect on activity is exerted by the PON1-192 polymorphism. However, the PON155 polymorphism also exerts a smaller, but significant, effect on activity $^{20}$.

Therefore, the idea of the current study was to measure PON1 activity and its relation to serum MDA, total proteins levels, AST and ALT activities in patients with chronic liver disease and determine whether or not PON1 activity can be a non-invasive marker of estimating the degree of liver damage in patients with chronic liver disease. Also, we investigated the PON1 gene polymorphism and its possible association with chronic liver disease. 


\section{METHODS}

The present study was conducted in the Medical Biochemistry and Internal Medicine Departments, Faculty of Medicine, Zagazig University.

One hundred subjects were enrolled in this study. All were divided into 4 groups

\section{Group I (Control group):}

This group comprised 25 subjects (15 males and 10 females). Their age ranged from 25 to 50 years, with a mean value of $35.3 \pm 6.5$ years. All were volunteers from relatives, colleagues and patients attending the Out Patient Clinics for minor complaint e.g. minor superficial injuries, ear wax...etc. They suffered no illness that might interfere with the present study. No medications were received for the past few weeks.

\section{Group II (Chronic Bilharzial patients):}

Twenty five patients (13 males and 12 females) were included in that group. Their age ranged from 27 to 45 years, with a mean value of $34.2 \pm 5$ years. Bilharizial infestation was detected by assessing bilharizial antibodies (indirect haemagglutination test) and proved by rectal snip examination.

\section{Group II (Chronic HCV group):}

Twenty five patients (17 males and 8 females) were included in that group. Their age ranged from 30 to 50 years, with a mean value of $38.7 \pm 6.4$ years. Patients were diagnosed as having chronic HCV by ELISA antibody assessment and confirmed by the presence of HCV-RNA by RTPCR estimation. All were negative for bilharzial infestation.
Group IV (Mixed bilharzial and HCV cirrhosis patients):

Twenty five patients (13 males and 12 females) were included in that group. Their age ranged from 35 to 60 years, with a mean value of $45.2 \pm 6.9$ years.

They were diagnosed as having both chronic pathological liver affection (HCV and bilhariziasis) by history, clinical examination and serological investigation.

All these individuals were subjected to thorough history taking, routine general and abdominal medical examination, plain X-ray of chest and heart, ultasonographic assessment of abdominal organs and routine laboratory investigations (urine and stool analysis, complete blood count....etc)

Blood sampling and DNA extraction

Six $\mathrm{ml}$ fasting venous blood samples were withdrawn from all the subjects and divided into 2 portions:

1. Three $\mathrm{ml}$ were placed in glass tubes with $\mathrm{K}_{2}$ EDTA and genomic DNA was obtained from leukocytes using QIA amp DNA Blood Mini Kit supplied by Qiagen GmbH, (Hilden, Germany). The purified DNA was safely stored at $-20^{\circ} \mathrm{C}$ for later use.

2. Three $\mathrm{ml}$ were collected into glass tubes with no anticoagulants, after being incubated at $37^{\circ} \mathrm{C}$ for 20 minutes and centrifuged to obtain serum, then serum were separated and stored at $-20^{\circ} \mathrm{C}$ till time of analysis.

Determination of PON Activity

PON1 activity assays were performed with $2 \mathrm{mmol} \mathrm{L}^{-1}$ paraoxon according to the method described by Mackness et al. ${ }^{\mathbf{2 1 , 2 2}}$. Initial hydrolysis rates of paraoxon (Sigma Chemical 
Co, UK) were determined by measuring the released p-nitro-phenol at $405 \mathrm{~nm}$ at $37{ }^{\circ} \mathrm{C}$ on a Milton Roy Spectronic 3000 Array.The basal assay mixture included $2.0 \mathrm{mmolL}^{-1}$ paraoxon and $2.0 \mathrm{mmol} \mathrm{L}^{-1} \mathrm{CaCl} 2$ in $0.1 \mathrm{~mol} \mathrm{~L}^{-1}$ Tris-HCl buffer, $\mathrm{pH}=8.0$. To $350 \mathrm{uL}$ of reagent mixture, $10 \mathrm{uL}$ of serum was added. Enzyme activities were expressed in international units (U) per 1 litre of sera. An international unit is the amount of hydrolyzed substrate in umol per minute.

\section{Determination of PON genotype}

PON1 genotypes were determined following PCR according to previously published protocols $\mathbf{s}^{19,23}$. For the polymorphism at position 192 , sense primer 5'TATTGTTGCTGTGGGACCTGA G 3' and antisense primer 5' CACGCTAAACCCAAATACATCT C 3', which encompass the 192 polymorphic region of the human PON1 gene, were used. For the polymorphism at position 55, sense primer 5'GAAGAGTGATGTATAGCCCCAG3' and antisense primer 5' TTTAATCC-

AGAGCTAATGAAAGCC 3'were used. The PCR reaction mixture contained $100 \mathrm{ng}$ of DNA template, $0.5 \mu \mathrm{M}$ of each primer, $1.5 \mathrm{mMMgCl}$, $200 \mu \mathrm{M}$ of each dNTP and 1 unit of TaqDNA

polymerase(QiagenGmbH,Hilden,Ger man). After denaturing the DNA for $5 \mathrm{~min}$ at $95^{\circ} \mathrm{C}$, the reaction mixture was subjected to 46 cycles of 1 min denaturation at $94^{\circ} \mathrm{C}, 30 \mathrm{~s}$ of annealing at $61^{\circ} \mathrm{C}$ and $1 \mathrm{~min}$ of extension at $72^{\circ} \mathrm{C}$. For the polymorphism at position 192, the 99 bp PCR product was digested with 8 units of AlwI restriction endonuclease (New England Biolabs, Cambridge, MA, U.S.A.) overnight at $37^{\circ} \mathrm{C}$, and the digested products were separated by electrophoresis on a $3 \%(\mathrm{w} / \mathrm{v})$ agarose gel and visualized using ethidium bromide. The $\mathrm{R}$ genotype (arginine) contains a unique AlwI restriction site which results in products of 66 and $33 \mathrm{bp}$, whereas the Q genotype (glutamine) would not be cut, allowing the PON1-192 genotype to be determined. For the PON1-55 polymorphism, the PCR reaction and cycling were the same as described above, except that 30 cycles were carried out. The PCR product (170 bp) was digested with NlaIII (New England Biolabs) in the presence of bovine serum albumin (BSA) $\left(37^{\circ} \mathrm{C}\right.$, overnight), and the digested products were separated and identifed as above. The L genotype (leucine) does not contain an NlaIII site, whereas the M genotpye (methionine) does contain an NlaIII site, giving rise to products of 126 and 44 bp.(Fig 2 and Fig.3).

\section{Measurement of Serum MDA Concentration}

Serum MDA levels were measured according to a method described elsewhere ${ }^{24}$. The principle of the method was based on the spectrophotometric measurement of the color occurring during the reaction of thiobarbituric acid with MDA. Concentration of thiobarbituric acid reactive substances (TBARS) was calculated by the absorbance coefficient of MDA-thiobarbituric acid complex and expressed in $\mu \mathrm{mol} / \mathrm{L}$. The traditional measures of liver function (serum alanine transaminase (ALT), and aspartate transaminase (AST) activities, as well 
as total proteins) were analyzed with standard techniques using Milton Roy Spectronic 3000 Array.

\section{RESULTS}

The results of the biochemical measurement in different studied groups are shown in (table 1). Serum activities of liver enzymes were significantly increased in all patient groups.

Serum PON1 activities were found to be significantly lower in all the studied groups in comparison to control group $(\mathrm{P}<0.001)$ (Fig. 1).

Also, serum MDA levels were significantly increased in all groups in comparison to control.

PON1 activity was positively correlated with serum total proteins, in group $\Pi$, $Ш$ and IV $(r=0.55,0.54$ and 0.71 respectively) and $(\mathrm{P}<0.001$ in all groups) but not in group I (control group). There was significant negative correlation between serum PON1 activity and serum ALT in group II, III and IV $(r=-0.58,-0.49$ and -0.47 , respectively and $\mathrm{P}<0.001$ in group II and $\mathrm{P}<0.01$ in group III and IV). There was also significant negative correlation between serum PON1 activity and serum MDA in group I, II, III, IV ( $\mathrm{r}=-0.75,-0.64,-0.87$ and $0.69)$ and $(\mathrm{P}<0.001)$ in all groups (Table 2).
Relationship between serum PON1 activity and genotypes

The distributions of the two polymorphisms in the control and in the patient groups with liver disease are shown in table (3). There were no significant differences in genotype or allele frequencies between cases and controls for either the PON1192 or PON155 polymorphisms. The mean decreases of serum PON1 activity in the patient groups relative to the control group were similar and independent of the genotype (Fig 4).

Multiple ANOVA showed that serum PON1 activities were significantly influenced $(\mathrm{P}<0.001)$ by both patients group and the polymorphisms PON155 and PON1192. The plasma concentration of MDA was higher in patients carrying the RR isoform (QQ: $69.5 \pm 5$. $1 \mu \mathrm{mol} / \mathrm{L} ; \mathrm{QR}: \quad 52.3 \pm 9.4 \mu \mathrm{mol} / \mathrm{L}$; QQ: $43.3 \pm 9 \mu \mathrm{mol} / \mathrm{L} ; \mathrm{P}<0.001$, RR vs. QR and QQ). In serum PON1 activity, it was the RR homozygote patients who were most able to hydrolyze paraoxon (QQ: $128.0 \pm 46.97 \mathrm{U} / \mathrm{L}$; QR: $217 \pm 54.4 \mathrm{U} / \mathrm{L} ; \mathrm{RR}: 276.4 \pm 47.1 \mathrm{U} / \mathrm{L} ; \mathrm{P}$ $<0.001, \mathrm{RR}$ and QR vs. QQ) (table4).

The plasma concentration of MDA was higher in patients carrying the $\mathrm{LL}$ isoform $(\mathrm{P}<0.0001$, LL vs. $\mathrm{ML}$ and $\mathrm{MM}$ ). In serum PON1 activity, it was the LL homozygote patients who were most able to hydrolyze paraoxon ( $\mathrm{P}<0.001$, LL vs. ML and MM) (table 4). 
Table 1. Results of the biochemical parameters in control and patient groups (Values are expressed as mean \pm SD)

\begin{tabular}{|l|c|c|c|c|}
\hline Groups & $\begin{array}{c}\text { Controls } \\
\mathbf{N}=\mathbf{2 5}\end{array}$ & $\begin{array}{c}\text { Chronic } \\
\text { Bilharzial group } \\
\mathbf{N = 2 5}\end{array}$ & $\begin{array}{c}\text { Chronic } \\
\text { hepatitis C } \\
\mathbf{N = 2 5}\end{array}$ & $\begin{array}{c}\text { Mixed bilharzial } \\
\text { and hepatitisC } \\
\text { cirrhosis N=25 }\end{array}$ \\
\hline $\mathrm{PON} 1(\mathrm{U} / \mathrm{L})$ & $412.9 \pm 99.8$ & $212.36 \pm 58.8^{*}$ & $191.7 \pm 75.3^{*}$ & $127.2 \pm 57.2^{*}$ \\
\hline $\mathrm{MDA}(\mu \mathrm{mol} / \mathrm{L})$ & $16.3 \pm 2.8$ & $46.99 \pm 11.6^{*}$ & $51.5 \pm 11.96^{*}$ & $50.1 \pm 12.36^{*}$ \\
\hline $\mathrm{ALT}(\mathrm{U} / \mathrm{L})$ & $27.1 \pm 1.9$ & $66.5 \pm 8.6^{*}$ & $88 \pm 10.8^{*}$ & $66.7 \pm 10.4^{*}$ \\
\hline $\mathrm{AST}(\mathrm{U} / \mathrm{L})$ & $23.4 \pm 6.8$ & $32.8 \pm 10.3^{*}$ & $70.5 \pm 12.5^{*}$ & $63 \pm 21.1^{*}$ \\
\hline Total protein $(\mathrm{g} / \mathrm{dl})$ & $7.1 \pm 0.3$ & $6.9 \pm 0.5$ & $7.1 \pm 0.3$ & $6.9 \pm 0.7$ \\
\hline
\end{tabular}

${ }^{*} \mathrm{P}<0.001=$ Highly significant.

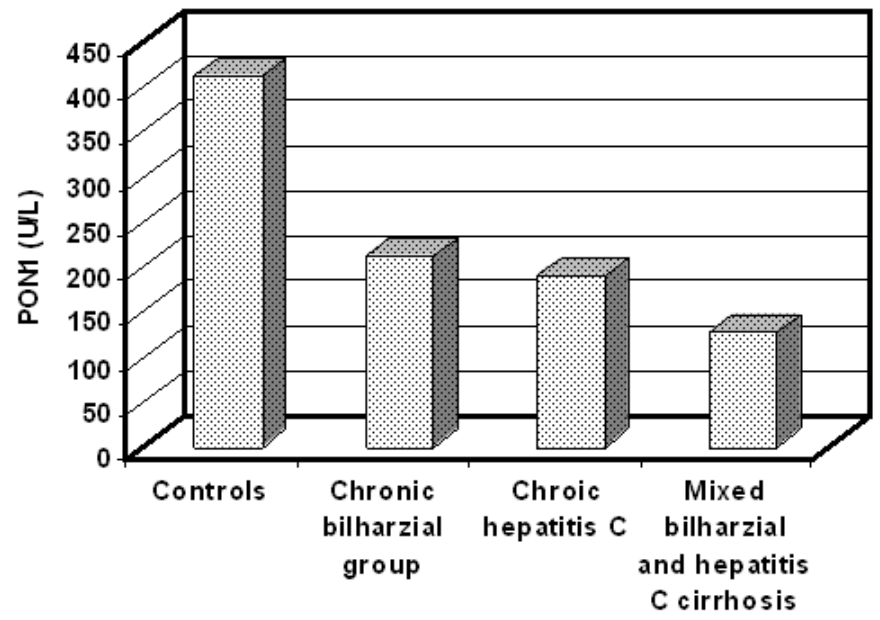

Fig. (1): Mean values $\pm S D$ of serum PON1 activity in all studied groups.

Table 2. Correlation coefficient of serum PON1, serum MDA and standard liver function test.

\begin{tabular}{|l|c|c|c|c|c|c|c|c|}
\hline & \multicolumn{2}{|c|}{$\begin{array}{c}\text { Controls } \\
\text { N=25 }\end{array}$} & \multicolumn{2}{c|}{$\begin{array}{c}\text { Chronic } \\
\text { Bilharzial } \\
\text { group N=25 }\end{array}$} & \multicolumn{2}{c|}{$\begin{array}{c}\text { Chronic } \\
\text { hepatitis C } \\
\text { N=25 }\end{array}$} & $\begin{array}{c}\text { Mixedbilharzial } \\
\text { and hepatitisC } \\
\text { cirrhosis N=25 }\end{array}$ \\
\cline { 2 - 9 } & $\mathbf{r}$ & $\mathbf{P}$ & $\mathbf{r}$ & $\mathbf{P}$ & $\mathbf{r}$ & $\mathbf{P}$ & $\mathbf{r}$ & $\mathbf{P}$ \\
\hline Total Protein & 0.03 & $>0.05$ & 0.55 & $<0.001 *$ & 0.54 & $<0.001 *$ & 0.71 & $<0.001 *$ \\
ALT & -0.22 & $>0.05$ & -0.58 & $<0.001 *$ & -0.49 & $<0.001 *$ & -0.47 & $<0.001 *$ \\
AST & -0.16 & $>0.05$ & -0.01 & $>0.05$ & 0.17 & $>0.05$ & -0.17 & $>0.05$ \\
MDA & -0.75 & $<0.001 *$ & -0.64 & $<0.001 *$ & -0.87 & $<0.001 *$ & -0.69 & $<0.001 *$ \\
\hline
\end{tabular}




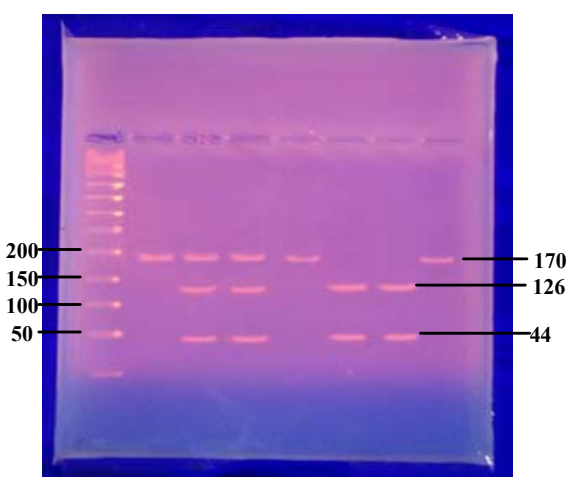

Fig. (2): Agarose gel electrophoresis pattern of PON1 55 polymrphism. Lane 1Molecular weight marker, lane 2, 5 and 8 show the homozygous LL. Lane 3 and 4 heterozygotes ML. Lane 6 and 7 show the homozygote MM.

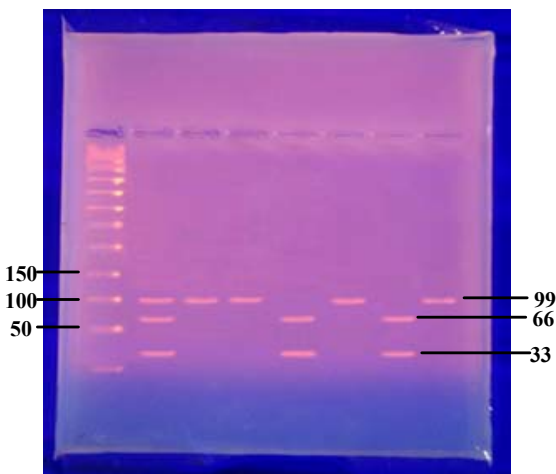

Fig.(3): Agarose gel electrophoresis pattern of PON1 192 polymrphism. Lane 1Molecular weight marker, lane 2 show the heterozygotes QR. Lane 3, 4, 6 and8 show the homozygous .QQ. Lane 5and 7 show the homozygote RR.

Table 3. Distribution of PON1 genotypes in patients and control for polymorphism at positions groups 55 and 192.

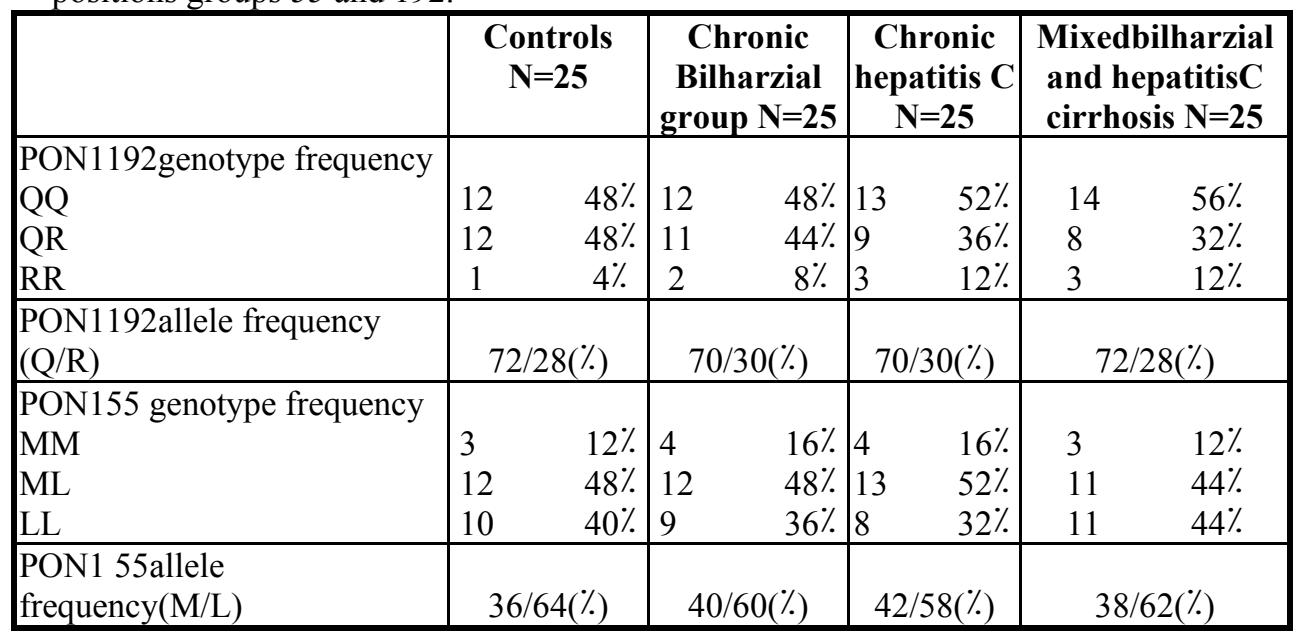


Table 4: Serum levels of PON1 activity \&MDA levels in relation to genotypes in all patient groups

\begin{tabular}{|l|c|c|c|c|c|}
\hline & $\begin{array}{c}\text { QQ } \\
\mathbf{N = 3 9}\end{array}$ & $\begin{array}{c}\mathbf{Q R} \\
\mathbf{N = \mathbf { 2 8 }}\end{array}$ & $\begin{array}{c}\mathbf{R R} \\
\mathbf{N = 8}\end{array}$ & $\mathbf{F}$ & $\mathbf{P}$ \\
\hline PON1 & $128.0 \pm 46.97$ & $217 \pm 54.5$ & $276.4 \pm 47.1$ & 43.59 & 0.001 \\
\hline MDA & $43.3 \pm 9$ & $52.3 \pm 9.4$ & $69.5 \pm 5.1$ & 31.09 & 0.0001 \\
\hline & $\mathrm{MM}$ & $\mathrm{ML}$ & $\mathrm{LL}$ & $\mathrm{F}$ & $\mathrm{P}$ \\
& $\mathrm{N}=11$ & $\mathrm{~N}=36$ & $\mathrm{~N}=28$ & & \\
\hline PON1 & $103 \pm 42.1$ & $155.7 \pm 52.4$ & $236.5 \pm 64.4$ & 27.64 & 0.001 \\
\hline MDA & $36.9 \pm 4.8$ & $48.1 \pm 8.3$ & $56.2 \pm 13.3$ & 14.6 & 0.0001 \\
\hline
\end{tabular}

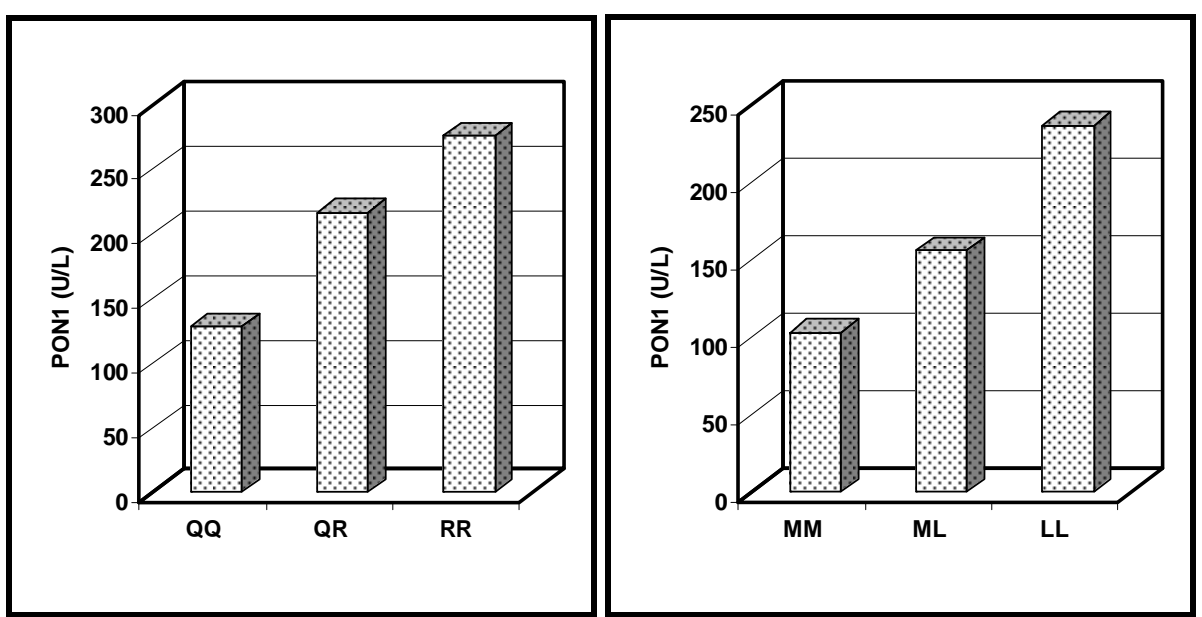

Fig. (4): Serum PON1activity (U/L) in all patients group in relation to genotype

\section{DISCUSSION}

Hepatitis $\mathrm{C}$ virus (HCV) infection is the major cause of chronic liver disease in most industrialized countries. There are $\sim 170$ million people in the world who are chronically infected by that virus. $\mathrm{HCV}$ viral infection frequently does not resolve, and $\sim 80 \%$ of the infected individuals become chronic carriers who may then progress to severe liver diseases. Approximately $10-20 \%$ of chronically infected hepatitis C patients will develop severe liver cirrhosis, and 1-5\% will develop hepatocellular carcinoma (HCC) within two to three decades of infection. HCV infection is also, the single major cause of liver transplantation in the U.S. ${ }^{25}$. Schistosomiasis is an important public health disease in many developing countries including Egypt. Hepatosplenic schistosomiasis is a serious manifestation of $\mathrm{S}$. mansoni infection that may lead to irreversible sequelae $^{26}$. The prevalence of HCV antibodies was greater in Egyptian patients with bilharziasis due to $\mathrm{HCV}$ 
transmission during antibilharzial parentral therapy or due to depressed cell mediated immunity in bilharzial patients ${ }^{27}$. It was proved that the state of oxidative stress at the sites of inflammation is responsible to a large extent for cellular damage and progression of fibrosis in chronic liver diseases $^{\text {28-30}}$. Evidence of oxidative stress has been detected in almost all the clinical and experimental conditions of chronic liver disease, often in association with decreased antioxidant defenses ${ }^{31-33}$. Therefore, antioxidant therapy is a promising strategy for treating or preventing oxidative stress related liver diseases.

Aviram et al. ${ }^{34}$ demonstrated that paraoxonase possesses an esterase and peroxidase like actions. PON1 peroxidase-like activity reduces L$\mathrm{OOH}$ to $\mathrm{L}-\mathrm{OH}$ and prevents intiation of LDL oxidation. PON1 can also interact with and remove specific lipid peroxides by acting stoichiometrically as a 'suicidal enzyme' with oxidized lipids as a 'biological buffer'. Consequently, the lowering of lipid peroxidation by PON1 can lead to alleviation of hepatic damage in the initial phase ${ }^{35}$.

It is accepted that arylesterase and PON1 activities are functions of a single enzyme ${ }^{36}$. In addition, in vitro biochemical studies indicate that hepatic and serum PON1 share many pharmacodynamic properties, as $\mathrm{Km}$, Vmax and effects of activators and inhibitors, etc. and which support the concept of a common identity for both paraoxonases $^{37}$.

Early studies had observed a significant decrease of serum arylesterase activity in patients with liver cirrhosis ${ }^{\mathbf{3 8 - 4 0}}$. Recently, there has been an increasing interest in paraoxonase and arylesterase as potential biomarkers for chronic liver impairment ${ }^{41-43}$. Decreased activities of both enzymes may contribute to liver dysfunction by effect on lipid metabolism and peroxidation ${ }^{43}$. Kilic et al. $^{42}$ found significant decrease in paraoxonase and arylesterase activities in patients with chronic hepatitis B virus infection. Moreover, paraoxonase plays a role in the regulation of oxidative stress and hepatic cell apoptosis events that are closely related to liver fibrosis ${ }^{44}$.

In the present study we investigated the importance of PON1 activity measurement in assessment of the degree of liver damage as well as the effect of PON1 55 and192 polymorphism in patients with chronic liver disease. Serum PON1 activity is reduced in patients with chronic liver disease and that decrease is related to the degree of liver damage as stated by that its level decrease in patients with combined bilharzial and hepatitis $\mathrm{C}$ cirrhosis more than in the other two patients groups. The decrease in serum PON1 activity in patients with chronic liver disease could be accepted as an evidence of increased lipid peroxidation since it was shown that a decrease in liver microsomal PON1 activity is an early biochemical change related to lipid peroxidation and liver injury observed in rats with carbon tetrachloride (CCL4)-induced cirrhosis ${ }^{\mathbf{4 5}}$. Additionally, same authors monitored the modulation of these processes by the dietary supplementation with zinc, a metal that possesses antioxidant and antifibrogenic properties. These findings are consistent with those of Ali 
$(2004)^{46}$ who found that the activities of paraoxonase and arylesterase were partially restored in liver and serum by chronic administration of zinc as compared to control mice in experimental S. mansoni model. Also, elevated level of PON1 significantly reduced the extent of liver injury caused by CCL4 adminstration ${ }^{35}$. It has been reported that PON1 is inactivated after hydrolyzing lipids peroxides ${ }^{34}$ and this is confirmed in our study by the increased levels of serum MDA in all patient groups.

Another possible explanation may be related to the fact that alteration in HDL structure and composition can affect PON1 activity ${ }^{47}$. It is known that patients with liver disease often present with lecithin: cholesterol acyl transferase deficiency ${ }^{48}$. As a consequence, cholesterol esters synthesis is impaired and HDL shows great changes in shape and structure ${ }^{49}$. Such abnormalities may affect serum PON1 activity.

In our study, serum MDA level was significantly increased in patients with chronic liver disease in relation to control group. Increased serum MDA level is one of the well known indicators of lipid peroxidation. Increased MDA levels and decreased serum PON1 activity reflect increased oxidative damage in patients with chronic liver disease.

There is a wide inter-individual variation in PON1 concentration and activity. That variation is for apart determined by common genetic variants (polymorphism) in the PON1 gene $^{50}$. Regarding the effect of PON1 polymorphisms on serum PON1 activity, the effects of the PON1 192 and PON155 polymorphisms were the same for both patients and control groups. Thus, QQ homozygotes have the lowest paraoxonase activity, while QR heterozygotes have intermediate activity and RR homozygotes have the highest activity. Also, MM homozygotes had significantly lower PON1 activity than LM heterozygotes, who in turn had lower PON1 activity than LL homozygotes. These results are in agreement with those reported by Sorenson et al. ${ }^{36}$; Mackness et al. ${ }^{\mathbf{5 1}}$; Ferre et al. ${ }^{\mathbf{5 2}}$.

In the present study the serum level of MDA varies with different PON1 genotypes and it was higher in patients carrying the RR isoform in PON1 192 genotypes and patients carrying the LL isoform in PON155 genotypes. We thus think that PON1 192 RR and PON1 55 LL alleles are more susceptible to develop disease associated with increased oxidative stress. However, this could not be ascertained because, our results indicated that the genotype and allele frequencies were not statistically different between patients with chronic bilharziasis, patients with chronic hepatitis $\mathrm{C}$ and patients with mixed bilharzial and hepatitis $\mathrm{C}$ cirrhosis or between all patients groups and control.

PON1 hydrolyses lipid peroxides and there is evidence to suggest that PON1Q is more efficient than PON1R ${ }^{51,53}$.

One study identified a significant association between PON1192 polymorphism and the presence of hepatitis $\mathrm{C}$ virus infection ${ }^{54}$. They demonstrated that patients with chronic hepatitis had a higher frequency of the RR isoform of the 192 polymorphism than healthy 
subjects and thus subjects carrying the $\mathrm{R}$ allele might be more susceptible to developing disease involving an increased oxidative stress $^{54}$. What may appear to be a paradox in thier study is that the genotype associated with a higher frequency in patients with hepatitis is also, associated with a higher PON1 activity in serum. One possible explanation for this could be that the enzyme has multiple active sites serving different purposes, one of which relates to the lipid peroxide decoupling. In support of this hypothesis, it has been demonstrated that the PON1 active site for protection against lipid peroxidation requires a free sulfhydryl group at cysteine-284, whereas the enzyme activity against paraoxon does not ${ }^{\mathbf{5 3}}$.

In an experimental study of Zhang et al. ${ }^{35}$ intramuscular electrotransfer of hPON1Q gene led to efficient expression of the PON1 in mice. Elevated level of PON1 significantly reduced the extent of liver injury caused by $\mathrm{CCL}_{4}$ administration. In addition, the hPON1Q gene transferred mice also, exhibited lower degrees of oxidative stress, reflected by reduced serum MDA concentration, in contrast to their control counterparts. These data provide compelling and mechanistic evidence for the importance of PON1 in regulation of liver injury.

However, in our study the genotype and the allele frequency were statistically nonsignificant between patients with chronic liver disease and controls and this could be probably due to lower number of participants, ethnic difference and to heterogeneous etiology of their diseases.
In conclusion, the present study indicated that decrease in the activities of paraoxonase may play a role in the pathogenesis of chronic liver disease. In addition, serum paraoxonase activity measurement may be a beneficial tool for assessing the degree of liver damage in patients suffering chronic hepatic diseases. Further studies are required to gain further insight on the role of PON1 polymorphism in relation to chronic liver diseases.

\section{REFERENCES}

1. Halim A-B, Garry RF, Dash S, and Gerber MA (1999): Effect of Schistosomiasis and Hepatitis on Liver Disease. Am. J. Trop. Med. Hyg., 60(6), 915-920.

2. Choi J, Lee KJ, Zheng Y, Yamaga AK, Lai MMC, and Ou JH (2004): Reactive oxygen species suppress hepatitis $\mathrm{C}$ virus RNA replication in human hepatoma cells. Hepatology 39: 81-89.

3. Mahmood S, Kawanaka M, Kamei A, Izumi A, Nakata K, Niiyama G,Ikeda H, Hanano S, Suehiro M, Togawa K, and Yamada G (2004): Immunohistochemical evaluation of oxidative stress markers in chronic hepatitisC. Antioxid Redox Signal 6: 19-24.

4. Facundo HTF, Brandt CT Owen JS and Lima VLM (2004): Elevated levels of erythrocyte-conjugated dienes indicate increased lipid peroxidation in schistosomiasis mansoni patients. Brazilian Journal of Medical and Biological Research 37: 957-962. 
5. Aviram M, Rosenblat M (2004): Paraoxonases 1,2, and 3, oxidative stress, and macrophage foam cell formation during atherosclerosis development. Free Radic Biol Med., 37:1304-16.

6. Draganov, D I and La Du, BN (2004): Pharmacogenetics of paraoxonases:a brief review.Naunyn Scmiedebergs Arch.Pharmacol., 369: 78-88.

7. Hassett C, Richter RJ, Humbert R, et al. (1991): Characterisation of cDNA clones encoding rabbit and human serum paraoxonase: the mature protein retains its signal sequence. Biochemistry., 30: 10141-10149.

8. Mackness MI, Arrol S, Durrington PN (1991): Paraoxonase prevents accumulation of lipoperoxides in low-density lipoprotein. FEBS (Lett)., 286: 152-4.

9. Mackness MI, Arrol S, Durrington PN (1993): Protection of low-density lipoprotein against oxidative modification by high-density lipoprotein associated paraoxonase. Atherosclerosis., 104: 129-35.

10. Watson AD, Berliner JA, Hama SY, La Du BN, Faull KF, Fogelman AM, et al. (1995): Protective effect of high density lipoprotein associated paraoxonase. Inhibition of the biological activity of minimally oxidized low density lipoprotein. J Clin Invest., 96: 2882-91.

11. Mackness MI, Durrington PN (1995): HDL, its enzymes and its potential to influence lipid peroxidation. Atherosclerosis., 115: 243-53.
12. Mackness M, Mackness B (2004): Paraoxonase 1 and atherosclerosis: is the gene or the protein more important? Free Radical Biol Med., 37: 1317-23.

13. Mackness B, Quarck R, Verreth W, Mackness $M$, Holvoet P (2006): Human paraoxonase-1 overexpression inhibits atherosclerosis in a mouse model of metabolic syndrome. Arterioscler, Thromb, Vasc Biol., 26:1545-50.

14. Marsillach J, Parra S, Ferré N, Coll B, Alonso-Villaverde C, Joven J, et al. (2008): Paraoxonase-1 in chronic liver diseases, neurological diseases, and HIV infection. In: Mackness B, Mackness M, Aviram M, Paragh G, editors. The Paraoxonases: Their Role in Disease Development and Xenobiotic Metabolism. Dordrecht: Springer., p. 187-98.

15. Rodrigo L, Gil F, Hernández AF, Marina A, Vázquez J, Pla A (1997): Purification and characterization of paraoxon hydrolase from rat liver. Biochem J., 321:595-601.

16. Reuben A (2007): Alcohol and the liver. Curr Opin Gastroenterol., 23: 283-91.

17. De Minicis $S$, Brenner DA (2007): NOX in liver fibrosis. Arch Biochem Biophys., 462: 266-72.

18. Deakin S, Leviev I, Guernier S, James RW (2003): Simivastatin modulates expression of the PON1 gene and increase serum paraoxonase: a role of sterol regulatory element binding protein $^{-2}$. Arterioscler. Thromb. Vasc. Biol., 63: 945-56. 
19. Humbert R, Alder DA, Disteche CM, Hassett C, Omiecinski CJ, Furlong CE (1993): The molecular basis of the human serum paraoxonase activity polymorphism. Nat Genet., 3: 736.

20. Mackness, B, Mackness,M.I, Arrol S, Turkie $W$ and Durrington PN (1997): Effect of the molecular polymorphisms of human paraoxonase (PON1) on the rate of hydrolysis of paraoxon. Br. J. Pharmacol., 112: 265-268.

21. Mackness MI, Harty D, Bhatnagar D, Wincour PH, Arrol S, Ishola $M$ and Durrington PN (1991): Serum paraoxonase activity in familial hyper-cholesterolaemia and insulin-dependent diabetes mellitus, Atherosclerosis., 86: 193-199.

22. Jureti D, Tadijanovi M, Reki B, Simeon-Rudolf V, Reiner $E$ and Bari M (2001): Serum paraoxonase activity in hemodialyzed uremic patients: cohort study. Croat. Med. J., 42: 146-150.

23. Adkins S, Gan KN, Mody M and La Du BN (1993): Molecular basis for the polymorphic forms of human serum paraoxonase/ arylesterase. Glutamine or arginine at position 191 for the respective A or B allozymes. Am. J.Hum. Genet., 52: 598-560.

24. Jain SK (1988): Evidence for membrane lipid peroxidation during the in vivo aging of human erythrocytes. Biochem Biophys Acta., 937: 205-10.

25. Choi J, Lu W, and Ou JH (2001): Structure and functions of Hepatitis C Virus core protein. Recent Res Devel Virol., 3: 105120.

26. Sayed HA, EL-Ayyat A, Kader AA, Sabry HY, Amer NM (2004): Epidemiology of Schistosoma mansoni infection and its relationship to snail distribution in a village at the Nile bank south to Cairo. Journal of the Egyptian Public Health Association., 79: 95-113.

27. El-Zayadi AR, Selim O, Ibrahim EH, Hamdy H, Dabbous H, Ahdy $A$ and Moneim SA (1997): Does Schistosomiasis play a role in the high sero prevalence of $\mathrm{HCV}$ antibody among Egyptians? Trop. Gastroenterol., 18(3): 98-100.

28. Gharib B, Abdallahi OM, Dessein H de-Reggi M (1999): Development of eosinophil peroxidase activity and concomitant alteration of the antioxidant defenses in the liver of mice infected with Schistosoma mansoni. Journal of Hepatology., 30: 594-602.

29. Friedman SL, Maher JJ, Bissell DM (2000): Mechanisms and therapy of hepatic fibrosis: report of the AASLD Single Topic Basic Research Conference. Hepatology., 32: 1403-1408.

30. Pinzani M, Gentilini P (1999): Biology of hepatic stellate cells and their possible relevance in the pathogenesis of portal hypertension in cirrhosis. Semin Liver Dis., 19: 397-410.

31. Pietrangelo A (1998): Iron, oxidative stress and liver fibrogenesis. J Hepatol; 28(Suppl 1): $8-13$.

32. Poli G, Parola M (1997): Oxidative damage and 
fibrogenesis. Free Radical Biol Med., 22: 287-305.

33. Parola M, Bellomo G, Robino G, et al. (1999): 4Hydroxynonenal as a biological signal: molecular bases and pathophysiological implications. Antioxidant Redox Signaling., 1: 255-284. 21. M. I.

34. Aviram M, Rosenblat M, Billecke S, et al. (1999): Human serum paraoxonase (PON1) is inactivated by oxidized low density lipoprotein and preserved by antioxidants. Free Radical Biol Med., 26: 892-904.

35. Zhang $C$, Peng $W$, Jiang $X$, Chen B. et al. (2008): Transgene expression of human PON1 Q in mice protected the liver against CCl4-induced injury. $\mathrm{J}$ Gene Med., 10: 94-100.

36. Sorenson RC, Primo-Parmo SL, Kuo CL, Adkins S, Lockridge O, La Du BN (1995): Reconsideration of the catalytic center and mechanism of mammalian paraoxonase/ arylesterase. Proc Natl Sci USA., 92: 7187-91.

37. Gonzalvo MC, Gil F, Hernandez AF, Rodrigo L, Villanueva E, Pla A (1998): Human liver paraoxonase (PON1): subcellular distribution and characterization. $\mathrm{J}$ Biochem Mol Toxicol., 12(1): 61-9.

38. Burlina A, Galzigna L (1974): Serum arylesterase isoenzymes in chronic hepatitis. Clin Biochem., 7(3): 202-5.

39. Burlina A, Michielin E, Galzigna L (1977): Characteristics and behavior of arylesterase in human serum and liver. Eur J Clin Invest., 7(1): 1720.
40. Kawai H, Sakamoto F, Inoue Y (1990): Improved specific assay for serum arylesterase using a water-soluble substrate. Clin Chim Acta., 188(2): 177-82.

41. Camps J, Marsillach J, Joven J (2007): Measurement of serum paraoxonase-1 activity as a potential biomarker for chronic liver impairment. Clinica Chimica Acta., 386: 114-115.

42. Kilic S, Aydin S, Kilic N, Erman F, Aydin S, Celik I (2005): Serum arylesterase and paraoxonase activity in patients with chronic hepatitis. World Journal of gastroenterology., 11: 7351-7354.

43. Aslan M, Horoz M, Nazligul Y, Bolukbas C, Bolukbas FF, Selek S, Aksoy N, Erel O (2007): Serum paraoxonase and arylesterase activities for the evaluation of patients with chronic hepatitis. International Journal of Clinical Practice., 62(7): 1050-1055.

44. Ferré N, Marsillach J, Camps J, Mackness B, Mackness M, Riu F, Coll B, Tous M, Joven J (2006): Paraoxonase-1 is associated with oxidative stress, fibrosis and FAS expression in chronic liver diseases. J Hepatol., 45(1): 51-9.

45. Ferre N, Camps J, Cabre M, et al. (2001): Hepatic paraoxonase activity alterations and free radical production in rats with experimental cirrhosis. Metabolism., 9: 997-1000.

46. Ali ME (2004): Arylesterase and paraoxonase in serum and liver of mice infected with Schistosoma mansoni: effect of zinc administration. Egyptian Journal of Biochemistry., 22: 123-138. 
47. James RW, Deakin SP (2004):

The importance of high density lipoprotein for paraoxonase-1 secretion, stability, and activity. Free Radic Biol Med., 37: 19861994.

48. Sabesin SM, Hawkins HL, Kuiken L, Ragland JB (1977): Abnormal plasma lipoproteins and lecithin-cholesterol acyltransferase deficiency in alcoholic liver disease. Gastroenterology., 72: 510-8.

49. Sabesin SM (1981): Lipid and lipoprotein abnormalities in alcoholic liver disease. Circulation., 64: 1172-1184.

50. Van Himbergen Tm, Tits LJH, Roest M, Stalenhoef AFH (2006): The story of PON1: how an organophosphate hydrolyzing enzyme is becoming a player in cardiovascular medicine. Review, Van Zuiden Communications, vol. 64, No. 2.

51. Mackness B, Mackness MI, Arrol S, Turkie W, Durrington PN (1998): Effect of the human serum paraoxonase 55 and 192 genetic polymorphisms on the protection by high density lipoprotein against low density lipoprotein oxidative modification. FEBS Lett., 423: 57-60.

52. Ferr'e, N, Camps J, Prats E, et al. (2002): Serum paraoxonase activity: a new additional test for the improved evalution of chronic liver damage. Clin. Chem., 48: 261-268.

53. Aviram M, Hardak E, Vaya J, Mahmood S, Milo S, Hoffman A, et al. (2000): Human serum paraoxonases (PON1) Q and R selectively decrease lipid peroxides in human coronary and carotid atherosclerotic lesions. PON1 esterase and peroxidaselike activities. Circulation., 101: 2510- 7 .

54. Ferre N, Marsillach J, Camps J, Rull A, et al. (2005): Genetic association of paraoxonase-1 polymorphisms and chronic hepatitis $\mathrm{C}$ virus infection. Clinica Chemica Acta., 361: 206210. 


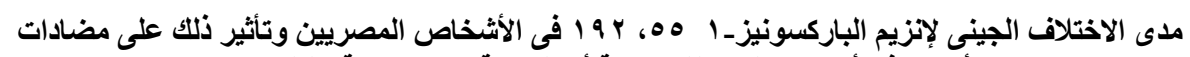

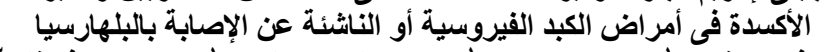

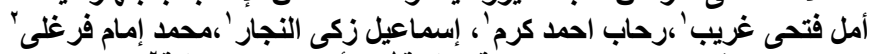

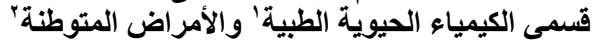

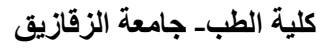

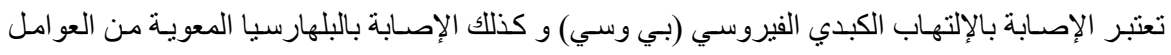

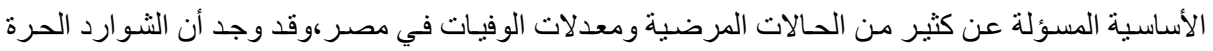

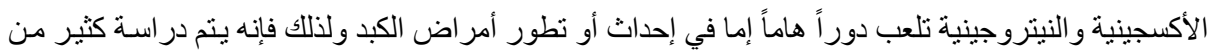

مضادات الأكسدة لتحديد دور ها في الوقاية أو علاج أمر اض اض الكبات الكبد المزمنة.

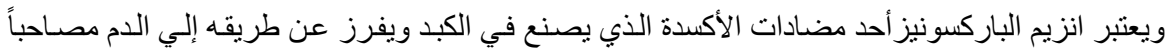

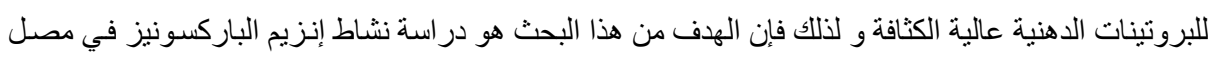

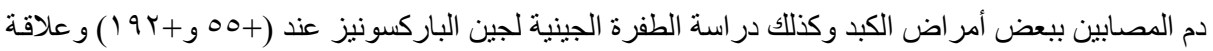

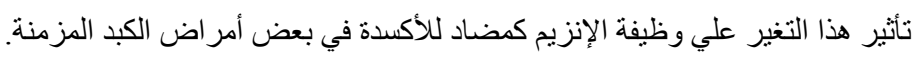

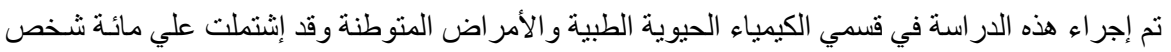

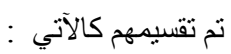

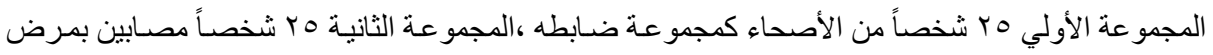

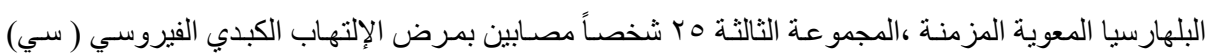

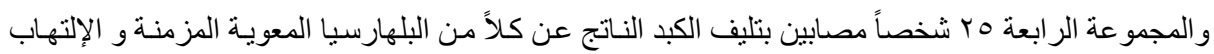

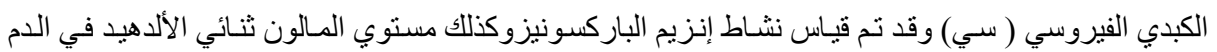

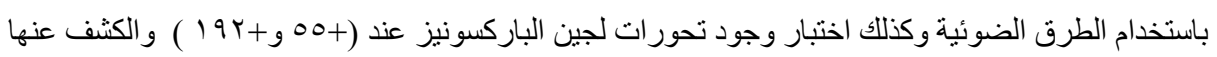

$$
\text { وأظهرت نتائتج البحث التناعلي التسلسلي عديد البلمرة. }
$$

يوجد إنخفاض ذو دلالية إحصائية في نشـاط إنزيم الباركسونيز في جميع المجموعات مقارنـة بالأصحاء

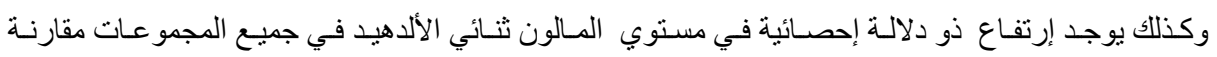

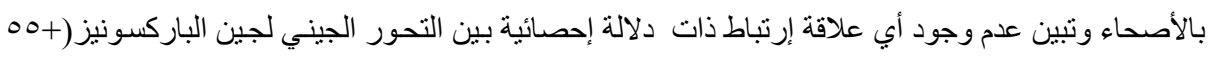

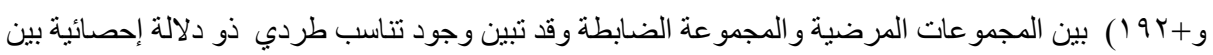

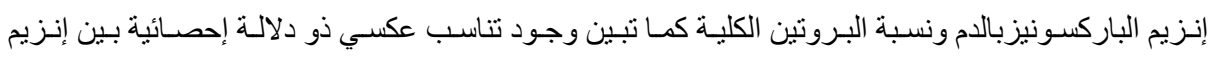

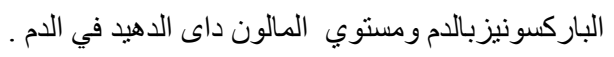

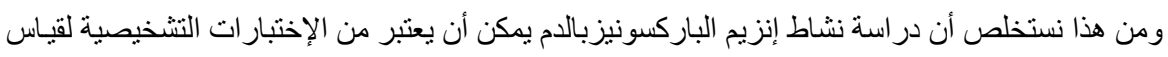

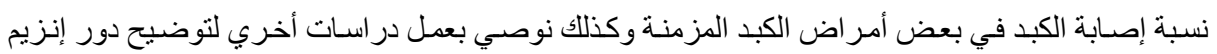
الباركسونيز و كذلك التحور الجيني لهذا الإنزيم في أمر اض الكبة الكبد المختلفة . 